\title{
Coiled-Coil Domain-Containing Protein
} 170

National Cancer Institute

\section{Source}

National Cancer Institute. Coiled-Coil Domain-Containing Protein 170. NCI Thesaurus. Code C118339.

Coiled-coil domain-containing protein 170 (715 aa, $\sim 82 \mathrm{kDa}$ ) is encoded by the human CCDC170 gene. This protein may play a role in bone development. 